\title{
Effect of $10 \%$ carbamide peroxide bleaching gels on surface hardness of nano filled composite resin
}

\author{
Deli Mona ${ }^{1 *}$, Indah Rismayansari ${ }^{1}$ \\ ${ }^{1}$ Department of Conservative Dentistry, Faculty of Dentistry Andalas University, Indonesia
}

\begin{abstract}
Introduction: Home bleaching is the whitening treatment of vital teeth applied by patients themselves at home under dentist supervision. In clinical condition, several patients who need bleaching treatment already had nano filled composite resin restoration on their teeth. The purpose of this study was to investigate the contact time difference of $10 \%$ carbamide peroxide bleaching gels application for home bleaching on the surface hardness of nano filled composite resin activated by Light Emitting Diode (LED). Methods: Total sample in this study was 30 samples, divided into 3 groups. The samples used were nano filled composite resin cylindrical shape with a diameter of $6 \mathrm{~mm}$ and a thickness of $2 \mathrm{~mm}$. Group I as the control group was immersed in distilled water, group II was treated with immersion in $10 \%$ carbamide peroxide for 4 hours per day, and group III was immersed in 10\% carbamide peroxide for 6 hours per day. The duration of treatment was 14 days for all groups. Data were analysed using Kruskal-Wallis with MannWhitney test and the p-value $=0.05$. Results: The result of one-way Kruskal-Wallis with Mann-Whitney test showed that there were significant difference between the control group and the groups applied with $10 \%$ carbamide peroxide for 4 hours and 6 hours per day with the $p$-value $0.00(p<0.05)$. Conclusion: Application of $10 \%$ carbamide peroxide decreasing the surface hardness of nano filled composite resins activated by LED.
\end{abstract}

Keywords: Nano filled composite resin, carbamide peroxide, composite resin hardness, Light Emitting diode (LED).

p-ISSN: 1979-0201; e-ISSN: 2549-6212; Available from: http://jurnal.unpad.ac.id/pjd/article/view/23794

DOI: 10.24198 /pid.vol31no3.23794

Submission: Jul 13, 2019; Accepted: Nov 20, 2019; Published online: Nov 30, 2019

\section{INTRODUCTION}

The teeth appearance determines individual appearance as a whole. Some factors that influence the teeth appearance are teeth colour, shape, position, and quality of the teeth restoration. Teeth colour is one of the factors that determine individual satisfaction with their teeth appearance. $^{1}$

Teeth whitening procedure (bleaching) can be done by using chemicals and natural ingredients. Generally, chemicals ingredients used in dentistry as teeth whitening products are hydrogen peroxide and carbamide peroxide. ${ }^{2}$ 
Carbamide peroxide is more commonly used as a home bleaching agent. The advantage of home bleaching is the application is relatively easy, more affordable, and the rate of its successes is high, but the use of chemicals in teeth whitening procedure is current-ly still debatable because it might also affect the oral hard and soft tissues. ${ }^{3}$

The use of teeth whitening agents in high concentrations and long periods might cause excessive sensitivity to the teeth and can harm the mucosa and gingiva. ${ }^{2}$ Negative effects during teeth whitening can be associated with low $\mathrm{pH}$, oxidation reactions, and the chemical compounds of teeth whitening agents. ${ }^{4}$

Factors that can affect the teeth whitening procedure included the type, concentration, and application duration of teeth whitening material, also, the light and temperature factors. Other factors that also influence are discolouration type, teeth colour before the whitening procedure, plaque and calculus which also has the potential to inhibit the process of teeth whitening. The $\mathrm{pH}$ value of the whitening material also affects the teeth whitening procedure. The $\mathrm{pH}$ value depends on the ma-terial used in the bleaching process. ${ }^{5}$ A low pH can erode the enamel surface. ${ }^{6}$ Another factor that influences the process of teeth whitening is the duration of whitening materials applied to the teeth. The longer the contact time of teeth whitening material with the surface of the teeth, the more noticeable teeth discolouration will become. ${ }^{7}$

Home bleaching procedure is also indicated for teeth with restoration. One of the materials of tooth restoration is compo-site resin. Based on the filler particle size, the composite resin is divided into the traditional, small-sized filler, microsized filler, hybrid, and nano filled. The later was introduced to the public for aesthetic needs with advantage on a glossy and smooth surface so it is often used for anterior teeth. ${ }^{8,9,10,11}$

Based on the polymerisation process, the composite resin is divided into chemical activated, light-activated and chemical-light activated (dual care). ${ }^{8,10,11}$ Light Emitting Diode (LED) activated composite resin is a new technology to polymerise restoration materials in dentistry and has a positive effect compared to halogen light.

The use of home bleaching in patients with composite resin restoration has generated controversy regarding the side effects of teeth whitening agents in restorations. Briso et $\mathrm{al}^{12}$ states that $15-16 \%$ carbamide peroxide can reduce the surface hardness of composite resins. Whilst Prabhakar et.al ${ }^{13}$ claims that $10 \%$ and $22 \%$ carbamide peroxide and can reduce the surface hardness of composite resin. Likewise, Campos et $\mathrm{al}^{14}$ published that there was no difference in the surface hardness effect of composite resin from several different samples after applying $10 \%$ and $15 \%$ carbamide peroxide. The purpose of this study was to investigate the contact time difference of $10 \%$ carbamide peroxide bleaching gels application for home bleaching on the surface hardness of nano filled composite resin activated by Light Emitting Diode (LED).

\section{METHODS}

The study design was an experimental laboratory with a post-test only control group conducted at the Laboratory of Microbiology of Faculty of Pharmacist and Laboratory of Metallurgy of Faculty of Engineering. The research samples was a disc-like nano filled composite resin restoration with a diameter of $6 \mathrm{~mm}$ and a thickness of $2 \mathrm{~mm}$. Total of samples were 30 samples, divided into 3 group, group I as control group (soaked in distilled water), group II as treatment group, applied with teeth whitening materials for 4 hours in 14 days, group III also as treatment group, applied with teeth whitening materials for 6 hours in 14 days.

The material used in this research was nano filled resin composite type Z350XT from 3M, teeth whitening material with brand Opalescence which contains $10 \%$ carbamide peroxide, and aquabides (distilled water). The tools used for this study were mould from stainless steel $(6 \mathrm{~mm}$ diameter and 2 $\mathrm{mm}$ thick), Gnatus brand LEDs, plastic instrument, press materials, incubator $37^{\circ} \mathrm{C}$, Shimadzu brand Vickers hardness test with, Micro Hardness Tester Type-M, cellophane strips, handscoon, mask, Petri dish, and board marker.

Procedure of this research showed in Figure 1, with descriptions as follows: (1) Fabrication of master model: Master model was made with moulds $6 \mathrm{~mm}$ in diameter and $2 \mathrm{~mm}$ thick; (2) Sampling procedure: The sample was divided into 3 groups; Group I as a control group consisted of 10 samples that were immersed in distilled water for 
24 hours and dried using water absorbent paper before changing the distilled water every 24 hours for 14 days, then incubated at $37^{\circ} \mathrm{C}$. Group II as test group consisted of 10 samples immersed in $10 \%$ carbamide peroxide for 4 hours then washed with distilled water for 1 minute and incubated at $37^{\circ} \mathrm{C}$ for 20 hours, repeated for 14 days. Group
III as test group had 10 samples immersed in $10 \%$ carbamide peroxide for 6 hours followed by cleansing with distilled water for 1 minute then incubated at $37^{\circ} \mathrm{C}$ for 18 hours, repeated for 14 days; (3) Hardness test was performed with the Vickers Hardness Test with the pressure of $100 \mathrm{gf}$ for 15 seconds.

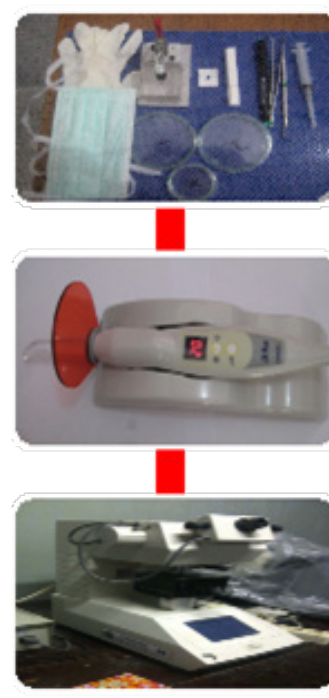

\section{RESULTS}

The data analysis was conducted using ANOVA test, and Kruskal-Wallis with Mann-Whitney Test in advance.

The one-way ANOVA results presented in Table 1 revealed the mean values and standard deviations of the surface hardness of nano filled composite resin in all groups with the value stated in the following consecutive order: $86.40 \pm 3.84842$ VHN for the control group (immersed in distilled water); $81.44 \pm 1.22251 \mathrm{VHN}$ for group II, which applied with whitening materials for 4 hours in 14 days; and $79.73 \pm 0.91320 \mathrm{VHN}$ for group III, which applied with whitening materials for 6 hours in 14 days.

The Kruskal-Wallis with Mann-Whitney test results showed in Table 2 described that group I, compared with group II, result-ed in $\mathrm{p}=0.005$ ( $\leq 0.05$ ) indicated a significant difference. Group I, compared with group III, resulted in $p=0.001$ ( $p$ $\leq 0.05$ ) means a significant difference. Group II, compared with group III, resulted in $\mathrm{p}=0.004$ ( $\leq 0.05$ ) also indicated a significant difference.
Table 1. Surface hardness nanofilled composite resin of treatment group

\begin{tabular}{cccc} 
& \multicolumn{3}{c}{ Hardness (VHN) } \\
\cline { 2 - 4 } 1 & I & II & III \\
2 & 79.10 & 79.73 & 80.17 \\
3 & 90.67 & 80.10 & 81.03 \\
4 & 90.87 & 79.73 & 79.63 \\
5 & 88.47 & 81.30 & 79.53 \\
6 & 88.00 & 82.83 & 80.57 \\
7 & 87.30 & 82.80 & 80.80 \\
8 & 88.80 & 82.50 & 78.83 \\
9 & 85.37 & 81.73 & 78.13 \\
10 & 82.37 & 82.33 & 79.30 \\
\hline Average & 83.07 & 81.33 & 79.30 \\
\pm SD & $\mathbf{8 6 . 4 0}$ & $\mathbf{8 1 . 4 4}$ & $\mathbf{7 9 . 7 3}$ \\
\hline
\end{tabular}

Table 2. Kruskal-Wallis with Mann-Whitney test results in all treatment groups

\begin{tabular}{lcc}
\hline & Group compared & P-value \\
\hline I-II & 0.005 \\
I-III & 0.001 \\
II-III & 0.004 \\
\hline
\end{tabular}

I: Control group (immersed in distilled water)

II: Treatment group, applied with teeth whitening materials for 4 hours in 14 days

III: Treatment group, applied with teeth whitening materials for 6 hours in 14 days 


\section{DISCUSSION}

The results presented in Table 1 suggested that there was a decrease in the surface hardness after bleaching with $10 \%$ carbamide peroxide for 4 and 6 hours compared to the control group (immersed in dis-tilled water). Control group had significant difference with group III, which was applied with whitening ma-terials for 6 hours in 14 days and decreased up to $6.67 \mathrm{VHN}$; while the control group decreased up to $4.96 \mathrm{VHN}$ compared with group II. The results also showed how the contact time of $10 \%$ carbamide peroxide influenced the surface hard-ness of nano filled composite resin. The data showed that the longer the contact time of $10 \%$ carbamide peroxide, the higher the decrease of surface hardness of nano filled composite resin.

Clinically, $10 \%$ carbamide peroxide and 35\% hydrogen peroxide showed a different effect on the teeth sensitivity. Sensitivity will happen until 2448 hours after the application of teeth whitening materials. Peroxide was detected in pulp 15 minutes after the enamel was exposed by $35 \%$ hydrogen peroxide. An in-vivo research procedure conducted with $10 \%$ carbamide peroxide using the home bleaching technique showed that the pulp condition was not changed to irreversible condition. ${ }^{15,16}$ Therefore, the use of $10 \%$ carbamide peroxide is more safe and effective for the teeth whitening procedure. The result of the present research was similar to a research conducted by Campos et $\mathrm{al}^{14}$, which discovered that composite resin contacted with teeth whitening material such as carbamide peroxide in the long term would have a decreasing surface hardness.

Kruskal-Wallis and Mann-Whitney Test results presented in Table 2 showed the significant difference be-tween control group and group applied with $10 \%$ carbamide peroxide, and there was also a significant dif-ference between group that applied with 10\% carbamide peroxide for 4 hours and 6 hours; which was con-sistent with research conducted by Tjuatja ${ }^{9}$, Briso ${ }^{12}$, and Prabhakar ${ }^{13}$, which discovered that hydrogen peroxide contained on carbamide peroxide that used for teeth whitening procedure affected significant decrease of surface hardness of composite resin.

Prabhakar $^{13}$ stated the use of $10 \%$ and $22 \%$ carbamide peroxide procedure affected a significant decrease in surface hardness of composite resin. $22 \%$ carbamide peroxide had more impact in decreasing the surface hardness compared to $10 \%$ carbamide peroxide on composite resin that applied for 8 hours per day in 14 days. ${ }^{13}$ Briso $^{12}$ also stated that the use of $16 \%$ carbamide peroxide from different whitening product brands such as Review $^{\mathrm{TM}}$, Magic Bleaching ${ }^{\mathrm{T} M}$, Opalescence ${ }^{\mathrm{TM}}$, Whiteness Product ${ }^{T M}$ and Claridex ${ }^{T M}$ also affected signifi-cant decrease of surface hardness of composite resin that applied for 6 hours per day in 14 days. The results of two later research was similar to the result of the current research.

Peroxide group in hydrogen peroxide will absorb more $\mathrm{H}_{2} \mathrm{O}$ molecules and will be diffused into polarised resin matrix, and this action will cause detachment of resin molecules and lead to resin matrix swelling. Swelling in the composite resin can cause pressure around resin composite filler, thus continues to structural degradation and ends up to the break of Si-O-Si bonds which bind the particle with silane (coupling agent). The rupture of $\mathrm{Si}-\mathrm{O}-\mathrm{Si}$ bond will also cause proton migration which will form Si-O bond, where the remaining of $\mathrm{Si}^{-}$atoms will bind with peroxide group from hydrogen peroxide. In the longer contact time, further degradation by peroxide will occur and able to cause the plastification of the resin matrix surface. ${ }^{9,10}$

Degradation of chemical composite resin structure not only affected the decrease of surface hardness but also cause microleakage activity, surface roughness and colour stabilisation on the composite resin. ${ }^{17-20}$ Ellias and Sajjan ${ }^{17}$ stated that teeth whitening materials formed microleakage between the teeth surface attachment and composite resin restoration. Microleakage is one of the causes of secondary caries through the initial procedure of the penetration of saliva liquid contained bacteria in restoration borders. ${ }^{17}$ Roughness surface of composite resin restoration is related to plaque retention, plaque accumulation, and biofilm formation, that will trigger secondary caries. A study suggested that bacteria colonisation was formed from the rough restoration surface. ${ }^{11,12}$ Ellias and Sajjan ${ }^{17}$ suggested that hydrogen peroxide predication causes protein denaturation on organic material of dentin and enamel. Therefore, the ratio of organic components more increased compared to inorganic components thus change the enamel and 
dentin surface morphology and formed surface porosity. ${ }^{17}$

Porosity will affect the surface roughness of enamel and composite restoration. Wang et $\mathrm{al}^{20}$ suggested that the surface hardness of the tooth enamel and composite resin had significant differences after teeth whitening procedure. This research was found that the effect of teeth whitening materials provided more impact on the roughness surface of composite restoration compared with the tooth enamel. ${ }^{20}$ This condition happened due to the broken chain of matrix and filler caused by free radicals of peroxide, thus leads to microscopic cracks and modification surface hardness of composite resin restoration. Li et al ${ }^{19}$ showed the period of teeth whitening materials application to composite resin restoration impact in increasing free radical of peroxide and increased the broken chain of matrix and filler and finally altered the surface roughness of composite resin restoration. ${ }^{19}$

\section{CONCLUSION}

Application of $10 \%$ carbamide peroxide bleaching gels used in home bleaching decreasing the surface hardness of nano filled composite resins activated by LED.

\section{REFERENCES}

1. Bailey SJ, Swift E Jr. Effect of home bleaching products on composite resins. Quintessence Int. 1992; 23(7): 489-94.

2. Heymann HO. Tooth whitening: facts and fallacie. Br Dent J. 2005; 198(8): 514. DOI: 10.1038/sj.bdj.4812298

3. Carey CM. Tooth Whitening: What We Now Know. J Evid Based Dent Pract. 2014; 14 Suppl: 70-76. DOI: $10.1016 /$ j.jebdp.2014.02.006

4. Alqahtani MQ. Tooth-bleaching procedures and their controversial effects: A literature review. Saudi Dent J. 2014; 26(2): 33-46. DOI: 10.1016/j.sdentj.2014.02.002

5. Haywood VB. History, safety, and effetiveness of current bleaching techniques and applications of the nightguard vital bleaching technique. Quintessence Int. 1992; 23: 47188.
6. Attin T, Hannig C, Wiegand A, Attin R. Effect of bleaching on restorative materials and restoratiion-a systematic review. Dent Mater. 2004; 20(9): 852-61. DOI: 10.1016/j. dental.2004.04.002

7. Ahn HJ, Song KB, Lee Ye, Lee JT, Cho SA, Kim $\mathrm{KH}$. Surface Change of Dental Amalgam after Treatment with $10 \%$ Carbamide peroxide. Dent Mater J. 2006; 25(2): 303-8. DOI: 10.4012/ dmj.25.303

8. Zekonis R, Matis BA, Cochran MA, Al Shetri SE, Eckert GJ,Carlson TJ. Clinical evaluation of in-office and at-home bleaching treatments. Oper Dent. 2003; 28(2): 114-21.

9. Tjuatja L, Mulyawati E, Halim FS. Perbedaan kekerasan mikro permukaan resin komposit mikrofil dan nanofil pada penggunaan bahan karbamid peroksida $45 \%$ dan hidrogen peroksida $38 \%$ secara in office bleaching (penelitian eksperimental laboratoris). J Ked Gi. 2011; 2(4): 264-70.

10. Anusavice KJ. Phillip's science of dental material. $12^{\text {th }}$ ed. St. Louis: Saunders-Elsevier; 2003. p. 227-43.

11. Powers JM, Sakaguchi RL. Dental Materials: Properties \& Manipulation (Craig). $12^{\text {th }}$ ed. St. Louis: Mosby Elsevier; 2006. p. 68-84.

12. Briso AL, Tuñas IT, de Almeida LC, Rahal V, Ambrosano GM. Effect of Five Carbamide Peroxide Bleaching Gels on Composite Resin Microhardness. Acta Odontol Latinoam. 2010; 23(1): 27-31.

13. Prabhakar AR, Sahana S, Mahantesh T, Vishwas TD. Effect of different concentrations of bleaching agent on the micro hardness and shear bond strengrth of restorative materials - an in vitro study. J Dent Oral Hyg. 2010; 2(1): 7-14.

14. Campos I, Briso AL, Pimenta LA, Ambrosano G. Effects of bleaching with carbamide peroxide gels on microhardness of restoration materials. J Esthet Restor Dent. 2003; 15(3): 175-82; discussion 183. DOI: $10.1111 / \mathrm{j} .1708$ 8240.2003.tb00187.x

15. Matis BA. Tray Whitening; What the Evidence Show. Compend Contin Educ Dent. 2003; 24(4A): 354-62.

16. Schulte JR, Morrissette DB, Gasior EJ, Czajewski MV. The Effect of Bleaching 
Application Time on the Dental Pulp. J Am Dent Assoc. 1994; 125(10): 1330-5. DOI: 10.14219/jada.archive.1994.0177

17. Ellias E, Sajjan G. Effect of Bleaching on Microleakage of Resin Composite Restorations in Non vital Teeth: $A n$ in vitro study. Endodontol. 2002; 14: 9-13.

18. Yap AU, Wattanapayungkul P. Effect of In office Tooth Whiteners on Hardness of Tooth colored Restoratives. Oper Dent. 2002; 27(2): 137-41.
19. Li Q, Yu H, Wang Y. Colour and Surface Analysis of Carbamide Peroxide Bleaching Effects on The Dental Restorative Materials in situ. J Dent. 2009; 37(5): 348-56. DOI: 10.1016/j. jdent.2009.01.003

20. Wang L, Francisconi LF, Atta MT, dos Santos JR, Del Padre NC, Gonini A Junior, et al. Effect of Bleaching Gels on Surface Roughness og Nanofilled Composite Resins. Eur J Dent. 2011; 5(2): 173-79. 